Article

\title{
Bridging Gaps in the Agricultural Phosphorus Cycle from an Animal Husbandry Perspective-The Case of Pigs and Poultry
}

\author{
Michael Oster ${ }^{1}$, Henry Reyer ${ }^{1}$, Elizabeth Ball ${ }^{2}$, Dario Fornara ${ }^{2}$ (D), John McKillen ${ }^{2}$, \\ Kristina Ulrich Sørensen ${ }^{3}$, Hanne Damgaard Poulsen ${ }^{3}$, Kim Andersson ${ }^{4}$, Daniel Ddiba ${ }^{4}$, \\ Arno Rosemarin ${ }^{4}$, Linda Arata ${ }^{5}$ (D), Paolo Sckokai ${ }^{5}$ (D), Elizabeth Magowan ${ }^{2}$ and \\ Klaus Wimmers $1,6, *$ (D) \\ 1 Institute of Genome Biology, Leibniz Institute for Farm Animal Biology (FBN), Wilhelm-Stahl-Allee 2, \\ 18196 Dummerstorf, Germany; oster@fbn-dummerstorf.de (M.O.); reyer@fbn-dummerstorf.de (H.R.) \\ 2 Agri-Food and Biosciences Institute, Large Park, Hillsborough, Co Down BT26 6DR, UK; \\ Elizabeth.Ball@afbini.gov.uk (E.B.); Dario.Fornara@afbini.gov.uk (D.F.); John.McKillen@afbini.gov.uk (J.M.); \\ Elizabeth.Magowan@afbini.gov.uk (E.M.) \\ 3 Department of Animal Science, Aarhus University, Blichers Allé 20, 8830 Tjele, Denmark; \\ krus@anis.au.dk (K.U.S.); hdp@anis.au.dk (H.D.P.) \\ 4 Stockholm Environment Institute, Linnégatan 87D, 10451 Stockholm, Sweden; \\ kim.andersson@sei.org (K.A.); daniel.ddiba@sei.org (D.D.); arno.rosemarin@sei.org (A.R.) \\ 5 Dipartimento di Economia agro-alimentare, Università Cattolica del Sacro Cuore, Via Emilia Parmense 84, \\ 29122 Piacenza, Italy; Linda.Arata@unicatt.it (L.A.); paolo.sckokai@unicatt.it (P.S.) \\ 6 Faculty of Agricultural and Environmental Sciences, University Rostock, Justus-von-Liebig-Weg 8, \\ 18059 Rostock, Germany \\ * Correspondence: wimmers@fbn-dummerstorf.de; Tel.: +49-38208-68-600
}

Received: 15 April 2018 ; Accepted: 29 May 2018 ; Published: 1 June 2018

Abstract: Since phosphorus (P) is an essential element for life, its usage and application across agricultural production systems requires great attention. Monogastric species such as pigs and poultry can significantly contribute to global food security but these animals remain highly dependent on the supply of mineral inorganic $\mathrm{P}$ in their feeds. Pig and poultry, which represent $70 \%$ of the global meat production, are also major $\mathrm{P}$ excretors and thus represent important sources of environmental $\mathrm{P}$ inputs. Balancing the $\mathrm{P}$ cycle within farming systems is crucial to achieve $\mathrm{P}$ sustainable and resilient livestock production. Therefore, the interconnection of animal feed, livestock farming, manure, and soil/aquatic ecosystems requires multidisciplinary approaches to improve $\mathrm{P}$ management. With regard to a sustainable agricultural $\mathrm{P}$ cycle, this study addresses aspects of feeding strategies and animal physiology (e.g., phase feeding, P conditioning, liquid feeding, phytase supplementation, genetics), soil agroecosystems (e.g., P cycling, P losses, P gains), reuse and recycling (e.g., manure, slaughter waste), measures of farmers' economic performance (e.g., bio-economic models), and $\mathrm{P}$ governance/policy instruments (e.g., P quota, $\mathrm{P}$ tax). To reconcile the economic and ecological sustainability of animal husbandry, the strategic objective of future research will be to provide solutions for a sufficient supply of high-quality animal products from resource-efficient and economically competitive agro-systems which are valued by society and preserve soil and aquatic ecosystems.

Keywords: agricultural cycle; bio-economic assessment; environmental phosphorus burden; farm animals; feeding strategies; monogastric species; phosphorus recycling; sustainable phosphorus governance 


\section{Introduction}

Phosphorus $(\mathrm{P})$ availability is very important for the functioning of natural and human-managed agricultural ecosystems where $P$ is cycled among plants, animals and soils [1,2]. In intensive agricultural production systems increased $\mathrm{P}$ availability can, however, lead to serious environmental problems, and improvements in $\mathrm{P}$ efficiency use are urgently required through the implementation of new sustainable management strategies [3-5].

Since the 1940s, the fossil mineral sources of phosphate rock have been intensively exploited to cover the food demand of an exponentially growing global population. At present about 240 megatons of high quality and accessible phosphate rock (ore) are mined per year and this is yearly increasing at a rate of $2 \%$ [6]. The geopolitics of $\mathrm{P}$ are only now being analyzed and the risks regarding potential shortages are high $[7,8]$. Global $P$ demand will continue to rise over the remainder of the twenty-first century due to the growing world population with increased demand for meat and dairy products, but also biofuels and mineral fertilizers. The accompanying massive fluctuations on the $\mathrm{P}$ rock market—e.g., with over 8-fold price increases in 2007 / 2008 [9] — considerably weaken the independence and competitiveness of the agricultural production chain. The looming gap between demand and supply, if unchecked, will jeopardize food production and hence food security.

Currently, about 17 megatons of $P$ are extracted annually, of which about 15 megatons are used in fertilizers. Of these, only $20 \%$ or about three megatons reach humans in the form of food [10-12]. There are major losses to soil and erosion through inefficient agro-practice and very little of the three megatons are recycled from our waste systems [13]. These inefficiencies can be partly attributed to the fact that age-related P requirements are in some cases considerably exceeded. Indeed, the required P supply decreases significantly with increasing live weight and matured skeletal system. Thus, over-supplementation practices lead to unnecessarily high P excretion rates [14]. Manure in intensive livestock farming contains a high P load [15] while causing serious concerns for both soil and aquatic ecosystems [16]. Many soils exposed to intensive livestock production in Europe exhibit excessive $\mathrm{P}$ amounts which negate achievement to match the objectives stated by the European Union's (EU) Water Framework Directive (2000/60/EC) and Urban Wastewater Treatment Directive (91/271/EEC). Thus, if efficiency and reuse potentials within the agricultural cycle were improved, sensitivity to $P$ scarcity, mineral $P$ price fluctuations, and $P$ environmental load could be reduced [17]. The aim of this study is to summarize the main factors and characteristics that contribute to improving the sustainable use of $\mathrm{P}$ in agriculture in an interdisciplinary manner.

\section{Approaches to Achieving P Sustainability from an Animal Husbandry Perspective}

Within the global P cycle, $\mathrm{P}$ is transferred both directly through P-containing rock reserves and indirectly through animal feed with its vegetable P components [10]. However, the P consumed by farm animals is to a certain extent excreted via manure and usually applied regionally on arable land and grassland. It is clear that the potential uses of $\mathrm{P}$ compete between agricultural systems to ensure food security for a growing world population [18]. For animal husbandry, this demands solutions to balance the $\mathrm{P}$ cycle in the monogastric pig and poultry farming (which represents about $70 \%$ of the global meat production [19]), hence contributing to a P-resilient livestock production that is resource-efficient and economically competitive.

Multidisciplinary experimental approaches are strongly required to trace the fate of $\mathrm{P}$ within the agricultural cycle of fodder plants, animals, microbiota, manure, and soil. In fact, $\mathrm{P}$ has a significant environmental impact if used inefficiently in animal husbandry (Figure 1). Possible approaches must be identified that reduce the dependency between population size of farm animals per area and environmental P load (Figure 1, solid line). Ideally, a population of farm animals can be supplied without harming its ecosystems, i.e., agro-ecological and non agro-ecological systems (Figure 1, dashed line). Moreover, combined and multidisciplinary efforts might lead to a scenario likely representing a shift towards a sustainable intensification (Figure 1, dotted line). In this context, there are several conceivable options to be discussed and experimentally validated (Figure 2). 


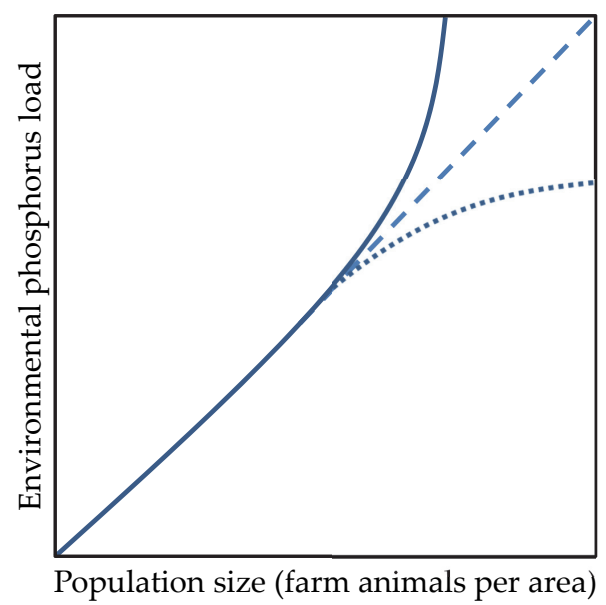

Figure 1. Scenarios illustrating the relationship between population size of farm animals per area and environmental P load. The solid line indicates P surplus areas due to P over-application. The dashed line indicates that a population of farm animals can be supplied without harming its ecosystem. The dotted line will lead to a reduction in the environmental impact of farm animal husbandry due to the combined approaches and knowledge derived from animal physiology, ecology, economy, recycling technics, policy, and governance.

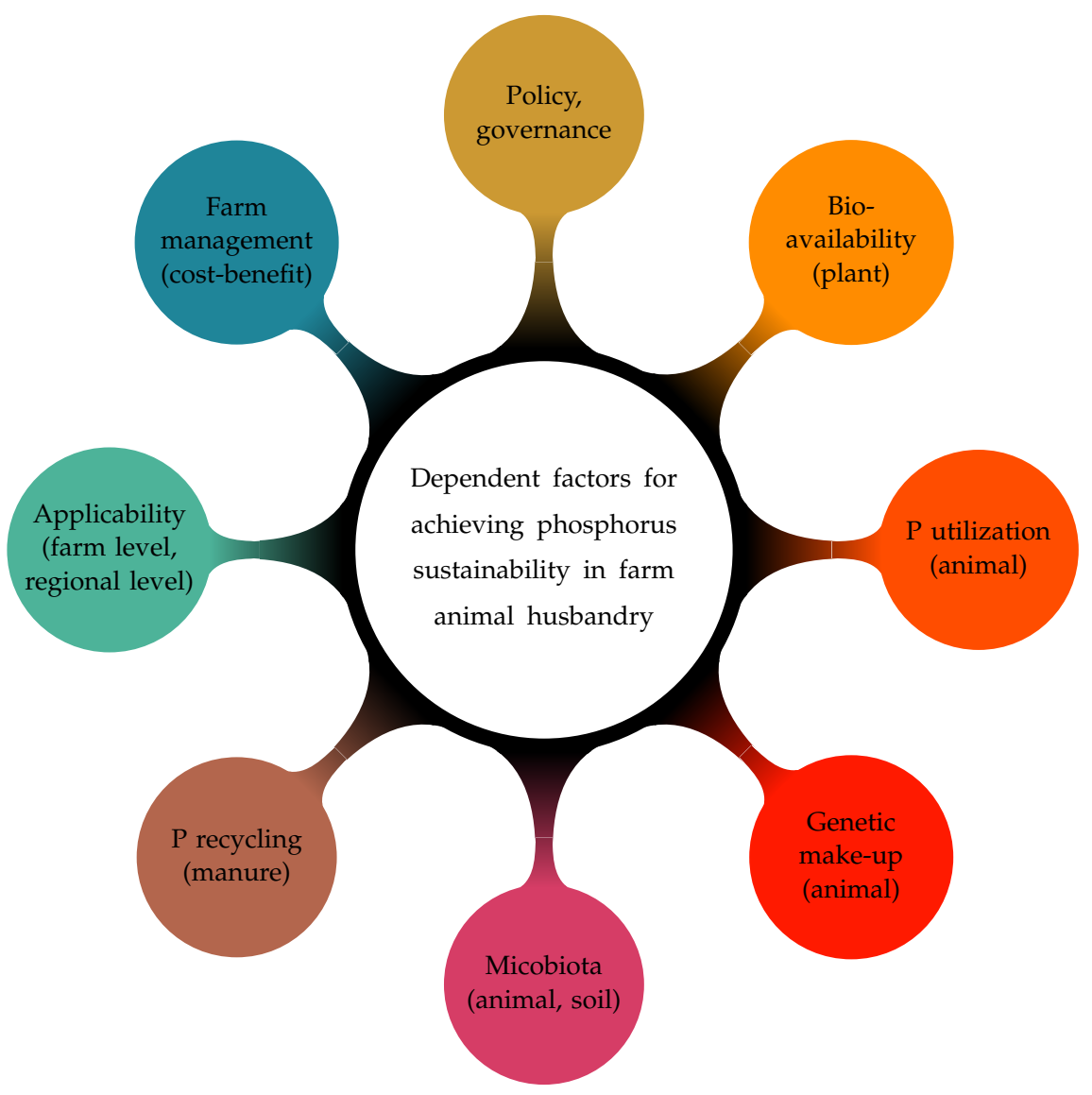

Figure 2. Approaches to achieving P sustainability from an animal husbandry perspective.

\subsection{Animal Nutrition}

To increase $\mathrm{P}$ efficiency in monogastric animals such as pigs and poultry, the genetic and physiological basis of $\mathrm{P}$ metabolism must be better understood at the molecular, cellular, organismal 
and microbiological levels. In intra- and intercellular body fluids, $\mathrm{P}$ is usually present as phosphate anions $\left(\mathrm{PO}_{4}{ }^{3-}, \mathrm{HPO}_{4}{ }^{2-}, \mathrm{H}_{2} \mathrm{PO}_{4}{ }^{-}\right)$, which carry out the various biological functions of $\mathrm{P}$. Indeed, $\mathrm{P}$ is of crucial importance for many aspects of animal and human metabolism, as it is involved in the formation of bone minerals, nucleic acids, and energy equivalents (Figure 3). Due to growth, metabolism, and physiological turn-over, the organism exchanges and subsequently also excretes $\mathrm{P}$ of endogenous origin which has to be steadily replaced by adequate diets [20]. In animal husbandry different dietary regimen and nutrients are discussed and evaluated with regards to $P$ requirement and feed/P efficiency, respectively.

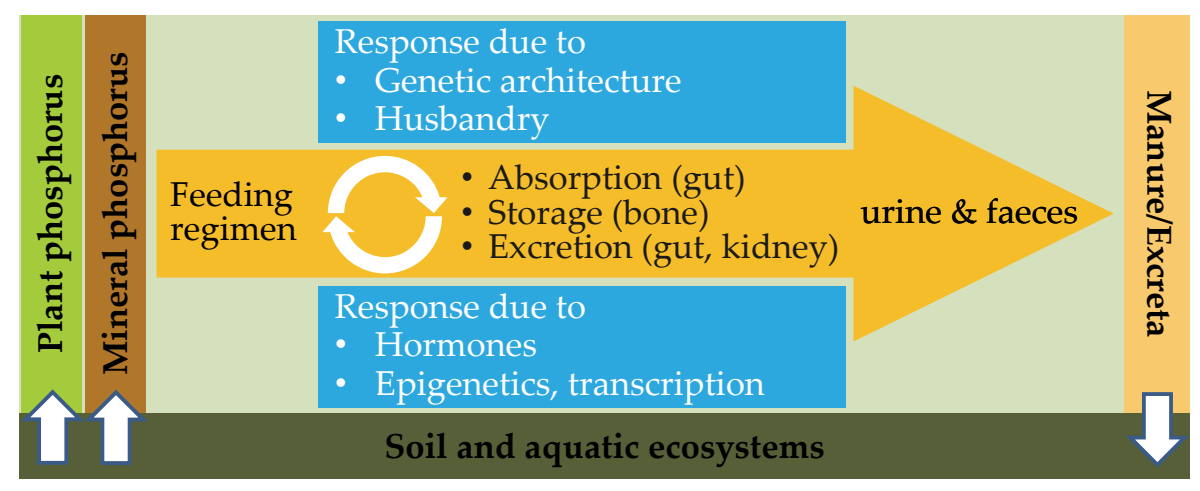

Figure 3. Animal-centered model of the agricultural P cycle. As P is important for all living organisms including monogastric species, dietary $\mathrm{P}$ requirements have to match utilization processes and $\mathrm{P}$ excretion rates due to physiological turn-over and endogenous losses (orange). Minimizing the mineral P supplementation and improving the P efficiency of animals depend on various factors such as (epi)genetics, husbandry, P digestibility, hormonal status, and transcription rates (blue).

\subsubsection{Feeding Regimen}

Nutrition has a great impact on P efficiency. Feeding recommendations probably need to be more intensively diversified according to the species-specific physiological conditions during rearing, fattening and reproduction stages (embryonal/fetal skeleton formation). The P homeostasis, i.e., maintaining a state of $\mathrm{P}$ equilibrium through endogenous regulatory processes, is primarily maintained by the intimate interplay between vitamin $\mathrm{D}$ (calcitriol), parathyroid hormone (PTH), calcitonin (CT) and fibroblast growth factor 23 (FGF23). These factors orchestrate the animal-intrinsic responses to balance absorption (gastrointestinal tract), storage (skeleton), and excretion rates (kidneys). Moreover, the P homeostasis also depends on several sometimes contradictory factors such as regulators, transporters, and endocrine and paracrine signals whose endocrine function and integration into networks have not yet been clearly identified [20-26]. Consequently, the mechanisms that mediate $\mathrm{P}$ homeostasis contribute to a significant phenotypical variation $[27,28]$. Accordingly, one important step to improve $\mathrm{P}$ efficiency and reduce $\mathrm{P}$ excretion is a finely graduated phase feeding or precision feeding regimen which is already used to a certain extent to adapt growth performance to ontogenetic requirements. Based on the number of feeding phases such strategies were shown to reduce P excretion by up to $38 \%$ [29] and increase the P efficiency to almost $50 \%$ in growing-finishing pigs by the strategic use of e.g., phytase [30].

Beside nutritional strategies focusing on postnatal periods [31,32], also prenatal development has proven to be sensitive to a variety of environmental and maternal factors [33-35]. Its adaptive response has been termed 'Metabolic Programming'. This phenomenon is characterized by long-term consequences for growth, function and structure of various tissues and therefore has implications on health and welfare of animals and humans [36,37]. The mechanism by which environmental and maternal cues are transmitted may involve the epigenetic regulation of specific genes [38,39]. This may offer the possibility to induce different and stable phenotypes as findings in animal models revealed adaptive responses which facilitate considerable organismal plasticity $[35,40,41]$. In fact, 
due to selective dietary $\mathrm{P}$ challenges, the adaptive responses are thought to be associated with endocrine, paracrine and autocrine regulation of $\mathrm{P}$ homeostasis. Consequently, a P conditioning throughout embryonal/fetal development might be effective in order to improve $\mathrm{P}$ efficiency in a cross-generational manner.

The apparent total tract digestibility of $\mathrm{P}$ in phytate rich cereals is low in monogastric animal species due to a short retention time of digesta in the stomach and anterior part of the small intestine where the $\mathrm{P}$ absorption takes place. In particular the jejunum is the main site of $\mathrm{P}$ absorption [42]. In this context, it is known that liquid feeding of pigs prolongs the time for enzymatic activity. This pre-digestion allows more phosphate groups to be released for absorption, which increases the total tract digestibility of $\mathrm{P}$ compared to dry feeding systems. However, several optimization steps of the liquid feeding conditions such as the duration of soaking, the $\mathrm{pH}$ value and temperature of diets, and the addition of enzymes are currently under evaluation in order to increase P utilization (e.g., [43]). In addition, indirect effects on $\mathrm{P}$ digestibility due to changes in the microbiota composition are increasingly being investigated. Indeed, possible interactions between microbiota and host, as already described for characteristics of feed efficiency, may be significant $[44,45]$. In this context, a potential impact mediated by the availability of mineral $\mathrm{P}$, inositol phosphates, and myo-inositol in feedstuff and digesta need to be considered [46].

Several studies focused on the question of optimal P supply using various phytases (e.g., [47-49]). Thereby, the anti-nutritive effect of phytate is minimized by enzymatic hydrolysis in the upper part of the digestive tract. In fact, as the phytate-bound $\mathrm{P}$ is only available to a limited extent for monogastric animals, microbial phytases are routinely used in the nutrition of pigs and poultry. Despite extensive trials in phytate/phytase research in the feeding of broilers and pigs, there is probably further potential to improve P efficiency through the evaluation of different phytase types, phytase dosages, phytase activity sites, dietary phytate contents, and feed ingredient composition. Because such treatments impact on P digestibility and P excretion rate, health and welfare measures need to be well documented. The introduction of transgenic pigs expressing bacterial phytase in the salivary gland to reduce fecal $\mathrm{P}$ losses has not yet proved marketable [50]. Therefore, alternative approaches must be identified to clarify whether endogenous phytases even exist and whether P absorption in distal intestinal tracts of chickens and pigs are of relevance [51]. In addition, other feeding strategies include (i) the use of regional cereals with different phytate profiles and (ii) usage of ingredients lowering the gastro-intestinal retention time for sufficient breakdown of phytate to improve intestinal $\mathrm{P}$ absorption.

Few studies with holistic approaches have focused on molecular metabolic pathways that are relevant for reduced and excessive P supply in farm animals [28,52]. Experiments elucidating the genotype-phenotype map will likely prove beneficial for the characterization of the molecular mechanisms of P efficiency. Hence, a more comprehensive understanding of P influxes and effluxes is required to derive physiological and (epi)genetic P efficiency potentials. In addition, systems biology analyses complement a holistic view of relevant metabolic pathways, which can be validated with mathematical and statistical approaches [53].

\subsubsection{Animal Welfare Aspects}

Welfare and health status are closely related to bone integrity and mineral metabolism but the skeleton also serves as a reservoir for minerals required for the various biological functions (Figure 3). Therefore, deviations from the currently recommended dietary P supply must be carefully considered. Indeed, dietary challenges associated with variable amounts of $P$ have had an impact on bone mineralization and bone microstructure $[54,55]$ and revealed implications on energy metabolism and nutrient utilization [56]. In this context, $P$ serum levels are a primary signal for activating endocrine responses, as thereby several known and yet to be elucidated regulators are addressed. Accordingly, as endogenous mechanisms affect important adaptive immune responses, research on $\mathrm{P}$ homeostasis requires considerable attention due to its importance in health and disease [57]. In pigs, interactions between the dietary P supply and the immune system can be deduced $[28,58]$. Hence, nutrition links 
the skeletal system with the immune system to a transdisciplinary field known as osteoimmunology $[59,60]$. It expands the insight into the repertoire of genes involved in P homeostasis and the molecular processes in the bone marrow niches which are a specialized microenvironment that modulate mineral homeostasis, bone formation, hematopoiesis, and immune functions according to the requirements of the organism and external stimuli. The structural and metabolic responses following divergent $P$ supplies suggest that further research is needed to comprehensively map and identify P-relevant molecular pathways to characterize an efficient mineral balance. In addition, consequences for bone health, biomechanics, bone microstructure, and mineral composition (i.e., of femora, metacarpal bones) will have to be captured to assess P efficiency in monogastrics and to further approximate dietary effects on animal health and welfare.

\subsubsection{Animal Genetics}

It has been shown that $\mathrm{P}$ homeostasis and therefore, individual $\mathrm{P}$ requirements are partially based on genetics (species, breed). Monogastric animal species appeared to have DNA variations contributing to the phenotypic variability of certain $P$ characteristics such as $P$ utilization $[27,61-63]$ and bone mineralization $[64,65]$. In chicken and quail populations, estimations have shown a considerable heritability of approximately $10 \%[62,63,66]$. However, holistic and genome-wide association studies (GWAS) for P-relevant traits are still missing for pig [67,68]. It can be assumed that the heritabilities are similar to quails and chicken, allowing the underlying genetic variation to be elucidated and subsequently used in breeding programs. Consequently, the genetic foundation of $\mathrm{P}$ efficiency provides opportunities to improve endogenous mechanisms of $\mathrm{P}$ utilization and to select $\mathrm{P}$ efficient animals.

\subsection{Phosphorus Reuse and Recycling}

Approximately 23.4 million tonnes of pork and about 13 million tonnes of poultry meat products are produced in the EU annually [69,70]. Along with these products, about 177 and 113 million tonnes of manure are generated respectively from pig and poultry farms annually which makes about one-fifth of all animal manure generated in the EU [71]. Recycling and reuse of P from manure can reduce the dependence on mineral fertilizers and also contribute to a reduction of $\mathrm{P}$ loads to fresh and marine water ecosystems. For the Baltic Sea for example, allowable levels of $\mathrm{P}$ and $\mathrm{N}$ inputs from each country and targets for reduction by 2016 have been agreed to [72]. However, studies have shown that previous reductions in P loads to coastal waters, in the case of Denmark for example, have been due to improved sewage treatment and lower point source emissions whereby no reductions in P loads from diffuse sources have been detected [73]. This underscores the need for stronger efforts to increase $P$ reuse and efficiency in agriculture.

The average dressing percentages for pigs and poultry range between $70 \%$ to $80 \%$ [74-76], reflecting the huge amounts of waste generated in slaughterhouse meat processing throughout the EU. Slaughter waste can be used to produce pet food and fertilizer, but in many cases it is incinerated or used to make porcelain [11]. The $\mathrm{P}$, which is currently incinerated or used for porcelain, must be recovered and used for agricultural purposes to enable a more resilient $P$ cycle.

In the EU, manure from pig and poultry farms is often used directly by spreading on agricultural land or as manure compost, separated solids from raw manure or digestate and as dried manure and pellets. While the huge amounts of $\mathrm{P}$ from pig and poultry manure have potential to contribute towards reducing the P mineral imports into the EU, the Nitrates Directive (91/676/EEC) limits nitrogen applications from manure origins to a maximum of $170 \mathrm{~kg} / \mathrm{ha} /$ year. This creates regions with excess manure and which are also constrained in transporting it to nutrient-deficient regions due to high transport costs, even though redistribution of manure has been shown to be effective in meeting targets for reduction of nutrient inputs to marine waters [77].

Over the years, several technologies have been developed for treating and processing manure even to the standard of generating by-products of such quality that they can be used in manufacturing chemical fertilizers $[78,79]$. Such technologies, some of which have been implemented at commercial 
scale could mitigate the reuse limitations of the Nitrates Directive by generating chemical fertilizer products from excess manure. However, these products would still be regarded as 'manure' since the EU's Fertilizers Regulations (2003/2003/EU) does not specify an animal by-product end point and consequently would be subjected to the same limits for animal manure as per the Nitrates Directive. Presently, only about $7.8 \%$ of all manure generated in the EU is processed [71] and there is limited knowledge of the full potential for $\mathrm{P}$ recycling from the several novel technologies that have emerged in recent years. Building on previous research, it will be important to quantify the potential of $P$ reuse and recycling from pig and poultry farming both on regional and national scales and to identify policy measures that can enable increased manure processing to generate reuse products, increased redistribution of manure between $\mathrm{P}$ surplus and $\mathrm{P}$ deficient areas and hence a more efficient and resilient $\mathrm{P}$ cycle in agriculture. It is also crucial to assess the impact of policies and regulations like the directive on promoting the use of renewable energy (for EU e.g., Directive 2009/28/EC) in creating incentives for the recovery of other resources and materials like biogas, clean water, and protein feed which have additional co-benefits.

\subsection{Phosphorus Impact on Soil Agroecosystems}

Agricultural grassland and farmed land represent important livestock-support systems, which are associated with large pools of $\mathrm{P}$ in both plant and soil compartments. The storage and temporal availability (and loss) of P from these soil pools can be greatly affected by the quality and quantity of animal slurries and manures returned to soils under intensive farm management. It is not clear how these organic nutrient amendments might actually influence the ability of grassland ecosystems to retain, use and cycle extra P loads between aboveground (i.e., plant biomass) and belowground compartments (i.e., plant roots and soils), especially in the long-term. Findings from a recent meta-analysis study show how $\mathrm{P}$ additions to soils contributed to increase total soil P pools, soil $P$ availability and soil microbial $P$ biomass [80]. Because nutrient fertilization can have long-term effects on soil $\mathrm{P}$ availability especially in surface horizons [81], it is likely that large P additions to soils will lead to nutrient leaching to water ecosystems. Changes in soil biogeochemical properties and/or changes in agricultural practices can alter P storage and availability in soils. For example, decreases in soil $\mathrm{pH}$ can increase phosphate availability because cations will be exchanged on clay particles and other surfaces [82]. Variation in soil P availability will influence $\mathrm{P}$ uptake rates in plants and the amount of $\mathrm{P}$ that could be lost through leaching, which can lead to serious eutrophication problems to freshwater systems [83]. There is also evidence of negative P-induced fertilization effects on plant species diversity and in general on biodiversity levels, which in grassland ecosystems tend to remain constantly low above thresholds in soil P of $104-130 \mathrm{mg} \mathrm{P} / \mathrm{kg}$ [84]. Chronic P additions can greatly affect plant-microbial symbioses including the abundance of arbuscular mycorrhizal fungi (AMF) and their role in uptaking P from soils [85]. More research is also needed to evaluate the role of plant roots in the uptake of extra P added to soils and to address whether changes in root length and/or root biomass could affect soil P availability and P leaching from grassland soils, which are chronically amended with animal manures.

Another important aspect is that nutrient additions to soils from animal wastes will include not only P but also other key nutrients such as nitrogen, which combined effects on ecosystem nutrient cycling are not clear yet. A recent meta-analysis study shows, however, that the combined addition of nitrogen and $\mathrm{P}$ to soils further contributes to increase plant $\mathrm{P}$ pools and also soil total $\mathrm{P}$, soil available $\mathrm{P}$ and soil microbial biomass $P$ [80]. Interestingly, the same study shows no relationship between these terrestrial $\mathrm{P}$ pools and the N:P ratio of added fertilizer (mainly inorganic fertilizer) suggesting that the relative abundance of $\mathrm{N}$ and $\mathrm{P}$ in fertilizers may not influence the net combined effects of $\mathrm{N}$ and $\mathrm{P}$ addition on plant and soil $\mathrm{P}$ pools. This finding (if confirmed) could have far reaching implications for ecosystem $P$ cycling in 'real-world' farming systems and more research is needed to understand how nitrogen and $P$ additions will affect $P$ gains and losses in soils amended with animal manures. Interestingly, the new Danish fertilizer legislation applicable from 2017 builds on an appropriate N:P 
ratio in fertilizer planning at local/regional level aiming to support the development of a concurrent balanced $\mathrm{N}$ and $\mathrm{P}$ strategy.

P cycling between aboveground and belowground compartments will depend on the interactive effects of the quality and quantity of $P$ inputs to soils and $P$ transformations, availability, and utilization within the soil-rhizosphere-plant system [85]. As discussed above, new nutrient management solutions at the farm scale could include more efficient animal feeding strategies which limit $P$ inputs to soils but also the promotion of higher diversification of agroecosystems, which could reduce $\mathrm{P}$ losses while optimizing both plant yields and ecosystem services [86]. The advantages of agricultural ecosystem diversification are likely greatest where farming inputs negatively affect environmental conditions and reduce the nutrient use efficiency of main crop species (Figure 1). Improvements in feeding with regard to a more balanced $\mathrm{P}$ supply in animals according to their need and high $\mathrm{P}$ digestibility may lead to reduced inputs to soils, which then promote a more efficient use of $\mathrm{P}$ by plant crop species which biomass could in return be fed to the animals.

\subsection{Policy and Governance}

Beyond technical and nutritive improvements to increase the efficiency in the use of P, policy measures aim to regulate the use of $\mathrm{P}$ at the farm level and represent instruments worthy to be analyzed [87]. These tools are being debated with regard to future agri-environmental policies and have already been implemented in some countries. In accordance with the existing provisions on nitrogen use, a typical policy tool may consist in the introduction of a P quota from manure and slurry to be spread on farmland. In fact, a P quota system is already in place in the Netherlands. The Dutch experience shows that complying with a $\mathrm{P}$ quota system is tough and an integration of several $\mathrm{P}$ management practices is required. In the Netherlands, the compound feed sector has recently started to reduce the amount of $\mathrm{P}$ in dairy feed, a practice which has been applied in diet considerations in US dairy farming during the last decades [88]. Efforts are also being made to apply this practice to pig nutrition. In Denmark, a tax on the use of supplemental inorganic mineral feed phosphate has been in force for more than 10 years in order to stimulate farmers to use plant $P$ more efficiently in livestock production resulting in a reduced use of feed phosphates. In addition, the introduction of a tax on $P$ inorganic fertilizers in order to discourage its non-efficient use might count as a market-based policy tool to improve the agricultural $\mathrm{P}$ cycle. However, their economic and environmental impact if applied to farms, regions, and countries with possibly divergent animal populations remains to be analyzed. It is also important to make an assessment of how proposed technical measures e.g., on feeding regimes, genetics, P reuse and recycling, and on-farm P efficiency, will contribute to meeting nutrient and natural resource-related targets in existing policies and regulations. These include the Nitrates Directive (91/676/EEC), the Industrial Pollution Prevention and Control Directive (2008/1/EC), the National Emission Ceilings Directive (2001/81/EC), the directive on promoting the use of renewable energy (Directive 2009/28/EC), the proposed EU Circular Economy package and other regional and national policies reviewed by Schröder et al. [11]. In addition, relevant national governance arrangements have to be reviewed to deduce recommendations to further develop sustainable P use.

\subsection{Farm Economics}

Bio-economic farm models are models which integrate farm level input-output relationships with economic data. Such models allow to assess technological innovations and policy changes $[89,90]$. However, there is a lack of current data on various P management strategies to assess the ecological and economic performance of farms [91]. Therefore, multidisciplinary research approaches focusing on animal biology, social ecology and economics are of decisive importance for monitoring the fate of P. Indeed, the results obtained from analyses described in Sections 2.1-2.4 need to be embedded in bio-economic models to assess their impact on the economic and environmental performance of farms. In addition to novel feeding strategies and technical innovations (Figure 2), the typology of pig and poultry farms will play an important role in bio-economic farm models. Specifically, 
the implementation of variables applicable to average representative farms could include farm size, farm location and intensification of the production process. Subsequent upscaling to regional and national levels could show the overall impact of any simulated strategy in terms of effectiveness in reducing environmental $P$ load.

\section{Conclusions}

This paper has shown that significant improvements in the sustainability and resilience of the agricultural P-cycle can only be achieved through interdisciplinary research approaches. The different aspects of animal, soil and plant sciences, economics, technology and politics as well as governance must be linked in order to make use of their mutual relations (Figure 4). To improve P use/reuse efficiencies along the entire value chain, agricultural research activities should focus on nutritional strategies and the biodiversity of monogastric P utilization. Considering cost-benefit assessments in various farm-, production-, and process-systems, defined approaches of how to improve soil management and manure practices will contribute to balancing economic and environmental sustainability with potential impacts on research and policy communities. Indeed this emphasis on pigs and poultry, which account for $70 \%$ of the global meat production, is a significant contribution to ensuring sustainable management of the world's limited P sources.

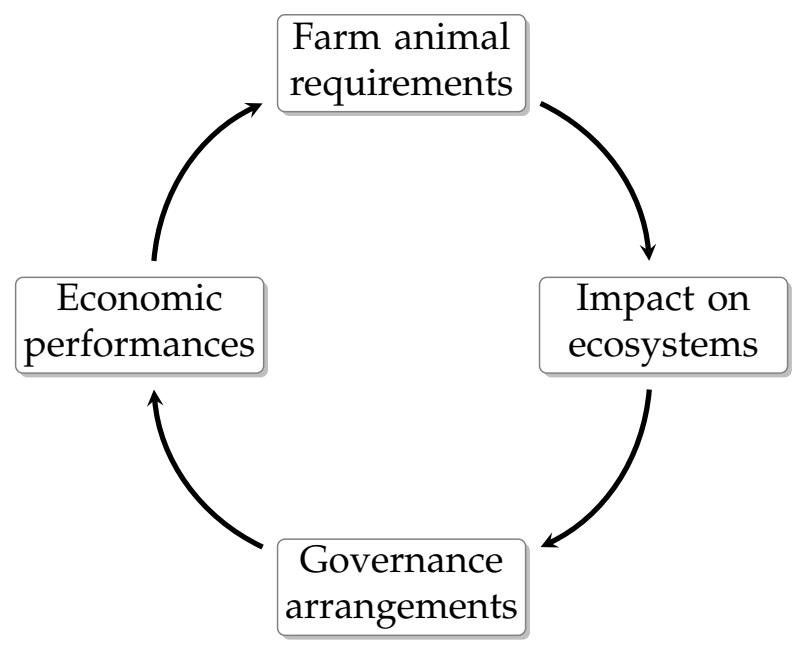

Figure 4. Dependencies from economy, animal husbandry, environment, and P governance. Animals are kept for reasons of food security and economic interest. Due to the species, animal excrements contribute to fertilize arable land which may result regionally in high environmental $\mathrm{P}$ load. The condition of the environment generates political action, which in turn regulates economic possibilities. Hence, multidisciplinary experimental approaches should cover all related subjects.

Author Contributions: The manuscript was developed as part of an ERA-Net project (www.pegasus.fbndummerstorf.de) in which all authors are currently involved. M.O., H.R., H.D.P., A.R., P.S., E.M., and K.W. conceived and designed the research; M.O., H.R., D.F., H.D.P., D.D., L.A., and K.W. drafted the paper; E.B., J.M., K.U.S., K.A., A.R., P.S., and E.M. edited and revised the manuscript; M.O., H.R., E.B., D.F., J.M., K.U.S., H.D.P., K.A., D.D., A.R., L.A., P.S., E.M., and K.W. approved the final version of the manuscript.

Funding: This work was partly funded by the Leibniz Science Campus Phosphorus Research Rostock and has received funding from the European Research Association Networks (ERA-NETs) Cofunds Sustainable Animal Production (SusAn) as part of the PEGaSus project (2817ERA02D). The Leibniz Institute for Farm Animal Biology (FBN) provided own matched funding. Department of Animal Science, Aarhus University covered some of the expenditures for running the pig experiments. The publication of this article was funded by the Open Access Fund of the Leibniz Association and the Open Access Fund of the Leibniz Institute for Farm Animal Biology (FBN).

Conflicts of Interest: The authors declare no conflict of interest. 


\section{References}

1. Cordell, D.; White, S. Life's bottleneck: Sustaining the world's phosphorus for a food secure future. Annu. Rev. Environ. Resour. 2014, 39, 161-188, doi:10.1146/annurev-environ-010213-113300. [CrossRef]

2. Withers, P.; van Dijk, K.; Neset, T.; Nesme, T.; Oenema, O.; Rubæk, G.; Schoumans, O.; Smit, B.; Pellerin, S. Stewardship to tackle global phosphorus inefficiency: The case of Europe. Ambio 2015, 44 (Suppl. 2), S193-S206, doi:10.1007/s13280-014-0614-8. [CrossRef] [PubMed]

3. Yamaji, N.; Takemoto, Y.; Miyaji, T.; Mitani-Ueno, N.; Yoshida, K.; Ma, J. Reducing phosphorus accumulation in rice grains with an impaired transporter in the node. Nature 2017, 541, 92-95, doi:10.1038/nature20610. [CrossRef] [PubMed]

4. Sharpley, A.; Kleinman, P.; Jarvie, H.; Flaten, D. Distant views and local realities: The limits of global assessments to restore the fragmented phosphorus cycle. Agric. Environ. Lett. 2016, 1, 1-5, doi:10.2134/ael2016.07.0024. [CrossRef]

5. Leinweber, P.; Bathmann, U.; Buczko, U.; Douhaire, C.; Eichler-Löbermann, B.; Frossard, E.; Ekardt, F.; Jarvie, H.; Krämer, I.; Kabbe, C.; et al. Handling the phosphorus paradox in agriculture and natural ecosystems: Scarcity, necessity, and burden of P. Ambio 2018, 47, 3-19, doi:10.1007/s13280-017-0968-9. [CrossRef] [PubMed]

6. Phosphate Rock. Mineral Commodity Summaries, U.S. Geological Survey. Available online: https://minerals. usgs.gov/minerals/pubs/commodity/phosphate_rock/mcs-2017-phosp.pdf (accessed on 10 April 2018).

7. Rosemarin, A.; Ekane, N. The governance gap surrounding phosphorus. Nutr. Cycl. Agroecosyst. 2015, 104, 265-279, doi:10.1007/s10705-015-9747-9. [CrossRef]

8. Report on Critical Raw Materials for the EU. Available online: http:/ / ec.europa.eu/DocsRoom/documents/ 10010/attachments/1/translations/en/renditions/native (accessed on 10 April 2018).

9. Heckenmüller, M.; Narita, D.; Klepper, G. Global Availability of Phosphorus and Its Implications for Global Food Supply: An Economic Overview; Technical Report; Kiel Institute for the World Economy (IfW): Kiel, Germany, 2014. Available online: http:/ /hdl.handle.net/10419/90630 (accessed on 10 April 2018).

10. Cordell, D.; Drangert, J.; White, S. The story of phosphorus: Global food security and food for thought. Glob. Environ. Chang. 2009, 19, 292-305. doi:10.1016/j.gloenvcha.2008.10.009. [CrossRef]

11. Schröder, J.; Cordell, D.; Smit, A.; Rosemarin, A. Sustainable use of Phosphorus, Report 357; Plant Research Institute, Wageningen University: Wageningen, The Netherlands; Stockholm Environment Institute: Stockholm, Sweden, 2010.

12. MacDonald, G.; Bennett, E.; Carpenter, S. Embodied phosphorus and the global connections of United States agriculture. Environ. Res. Lett. 2012, 7, 044024, doi:10.1088/1748-9326/7/4/044024. [CrossRef]

13. Ddiba, D. Estimating the Potential for Resource Recovery from Productive Sanitation in Urban Areas; KTH Royal, Institute of Technology: Stockholm, Sweden, 2016.

14. Poulsen, H.; Jongbloed, A.; Latimier, P.; Fernández, J. Phosphorus consumption, utilisation and losses in pig production in France, The Netherlands and Denmark. Livest. Prod. Sci. 1999, 58, 251-259. [CrossRef]

15. Barnett, G. Phosphorus forms in animal manure. Bioresour. Technol. 1994, 49, 139-147, doi:10.1016/0960-8524(94)90077-9. [CrossRef]

16. Steinfeld, H.; Gerber, P.; Wassenaar, T.; Castel, V.; De Haan, C. Livestock's Long Shadow: Environmental Issues and Options; Food \& Agriculture Org: Rome, Italy, 2006.

17. Cordell, D.; White, S. Sustainable Phosphorus Measures: Strategies and Technologies for Achieving Phosphorus Security. Agronomy 2013, 3, 86-116, doi:10.3390/agronomy3010086. [CrossRef]

18. Campbell, B.; Beare, D.; Bennett, E.; Hall-Spencer, J.; Ingram, J.; Jaramillo, F.; Ortiz, R.; Ramankutty, N.; Sayer, J.; Shindell, D. Agriculture production as a major driver of the Earth system exceeding planetary boundaries. Ecol. Soc. 2017, 22, 8, doi:10.5751/ES-09595-220408. [CrossRef]

19. Ritchie, H.; Roser, M. Meat and Seafood Production \& Consumption. Available online: https:/ / ourworldindata. org/meat-and-seafood-production-consumption (accessed on 10 April 2018).

20. Berndt, T.; Kumar, R. Novel mechanisms in the regulation of phosphorus homeostasis. Physiology 2009, 24,17-25, doi:10.1152/physiol.00034.2008. [CrossRef] [PubMed]

21. Mieczkowska, A.; Irwin, N.; Flatt, P.; Chappard, D.; Mabilleau, G. Glucose-dependent insulinotropic polypeptide (GIP) receptor deletion leads to reduced bone strength and quality. Bone 2013, 56, 337-342, doi:10.1016/j.bone.2013.07.003. [CrossRef] [PubMed] 
22. Pi, M.; Quarles, L. Novel bone endocrine networks integrating mineral and energy metabolism. Curr. Osteoporos. Rep. 2013, 11, 391-399, doi:10.1007/s11914-013-0178-8. [CrossRef] [PubMed]

23. Alshayeb, H.; Showkat, A.; Wall, B.; Gyamlani, G.; David, V.; Quarles, L. Activation of FGF-23 mediated vitamin D degradative pathways by cholecalciferol. J. Clin. Endocrinol. Metab. 2014, 99, E1830-E1837, doi:10.1210/jc.2014-1308. [CrossRef] [PubMed]

24. Proszkowiec-Weglarz, M.; Angel, R. Calcium and phosphorus metabolism in broilers: Effect of homeostatic mechanism on calcium and phosphorus digestibility. J. Appl. Poult. Res. 2013, 22, 609-627, doi:10.3382/japr.2012-00743. [CrossRef]

25. Oster, M.; Gerlinger, C.; Heide, K.; Just, F.; Borgelt, L.; Wolf, P.; Polley, C.; Vollmar, B.; Muráni, E.; Ponsuksili, S.; et al. Lower dietary phosphorus supply in pigs match both animal welfare aspects and resource efficiency. Ambio 2018, 47 (Suppl. 1), 20-29, doi:10.1007/s13280-017-0969-8. [CrossRef] [PubMed]

26. Morito, N.; Yoh, K.; Usui, T.; Oishi, H.; Ojima, M.; Fujita, A.; Koshida, R.; Shawki, H.; Hamada, M.; Muratani, M.; et al. Transcription factor MafB may play an important role in secondary hyperparathyroidism. Kidney Int. 2018, 93, 54-68, doi:10.1016/j.kint.2017.06.023. [CrossRef] [PubMed]

27. Bovo, S.; Schiavo, G.; Mazzoni, G.; Dall'Olio, S.; Galimberti, G.; Calò, D.; Scotti, E.; Bertolini, F.; Buttazzoni, L.; Samorè, A.; et al. Genome-wide association study for the level of serum electrolytes in Italian Large White pigs. Anim. Genet. 2016, 47, 597-602, doi:10.1111/age.12459. [CrossRef] [PubMed]

28. Just, F.; Oster, M.; Büsing, K.; Borgelt, L.; Murani, E.; Ponsuksili, S.; Wolf, P.; Wimmers, K. Lowered dietary phosphorus affects intestinal and renal gene expression to maintain mineral homeostasis with immunomodulatory implications in weaned piglets. BMC Genom. 2018, 19, 207, doi:10.1186/s12864-018-4584-2. [CrossRef] [PubMed]

29. Pomar, C.; Hauschild, L.; Zhang, G.; Pomar, J.; Lovatto, P. Applying precision feeding techniques in growing-finishing pig operations. Revista Brasileira de Zootecnia 2009, 38, 226-237, doi:10.1590/S1516-35982009001300023. [CrossRef]

30. Poulsen, H. Normtal for HusdyrgøDning [Standard Values for Danish Manure]. Available online: http: / / anis.au.dk/fileadmin/DJF/Anis/dokumenter_anis/Forskning/Normtal/Normtal_2017.pdf (accessed on 10 April 2018).

31. Valable, A.; Narcy, A.; Duclos, M.; Pomar, C.; Page, G.; Nasir, Z.; Magnin, M.; Létourneau-Montminy, M. Effects of dietary calcium and phosphorus deficiency and subsequent recovery on broiler chicken growth performance and bone characteristics. Animal 2017, 1-9, doi:10.1017/S1751731117003093. [CrossRef] [PubMed]

32. Gonzalo, E.; Létourneau-Montminy, M.; Narcy, A.; Bernier, J.; Pomar, C. Consequences of dietary calcium and phosphorus depletion and repletion feeding sequences on growth performance and body composition of growing pigs. Animal 2018, 12, 1165-1173, doi:10.1017/S1751731117002567. [CrossRef] [PubMed]

33. Hales, C.; Barker, D.; Clark, P.; Cox, L.; Fall, C.; Osmond, C.; Winter, P. Fetal and infant growth and impaired glucose tolerance at age 64. BMJ 1991, 303, 1019-1022, doi:10.1136/bmj.303.6809.1019. [CrossRef] [PubMed]

34. Howie, G.; Sloboda, D.; Kamal, T.; Vickers, M. Maternal nutritional history predicts obesity in adult offspring independent of postnatal diet. J. Physiol. 2009, 587, 905-915, doi:10.1113/jphysiol.2008.163477. [CrossRef] [PubMed]

35. Rehfeldt, C.; Lang, I.; Goers, S.; Hennig, U.; Kalbe, C.; Stabenow, B.; Bruessow, K.; Pfuhl, R.; Bellmann, O.; Nuernberg, G.; et al. Low and excess dietary protein levels during gestation affect growth and compositional traits in gilts and impair offspring fetal growth. J. Anim. Sci. 2011, 89, 329-341, doi:10.2527/jas.2010-2970. [CrossRef] [PubMed]

36. Ojha, S.; Fainberg, H.; Sebert, S.; Budge, H.; Symonds, M. Maternal health and eating habits: Metabolic consequences and impact on child health. Trends Mol. Med. 2015, 21, 126-133, doi:10.1016/j.molmed.2014.12.005. [CrossRef] [PubMed]

37. Fleming, T.; Watkins, A.; Velazquez, M.; Mathers, J.; Prentice, A.M.; Stephenson, J.; Barker, M.; Saffery, R.; Yajnik, C.; Eckert, J.; et al. Origins of lifetime health around the time of conception: Causes and consequences. Lancet 2018, 391, 1842-1852, doi:10.1016/S0140-6736(18)30312-X. [CrossRef]

38. Wolff, G.; Kodell, R.; Moore, S.; Cooney, C. Maternal epigenetics and methyl supplements affect agouti gene expression in Avy/a mice. FASEB J. 1998, 12, 949-957, doi:10.1096/fasebj.12.11.949. [CrossRef] [PubMed] 
39. Sebert, S.; Sharkey, D.; Budge, H.; Symonds, M. The early programming of metabolic health: Is epigenetic setting the missing link? Am. J. Clin. Nutr. 2011, 94 (Suppl. 6), 1953S-1958S, doi:10.3945/ajcn.110.001040. [CrossRef] [PubMed]

40. Bateson, P.; Barker, D.; Clutton-Brock, T.; Deb, D.; D’Udine, B.; Foley, R.; Gluckman, P.; Godfrey, K.; Kirkwood, T.; Lahr, M.; et al. Developmental plasticity and human health. Nature 2004, 430, 419-421, doi:10.1038/nature02725. [CrossRef] [PubMed]

41. Ashwell, C.; Angel, R. Nutritional genomics: A practical approach by early life conditioning with dietary phosphorus. Revista Brasileira de Zootecnia 2010, 39, 268-278, doi:10.1590/S1516-35982010001300030. [CrossRef]

42. McHardy, G.; Parsons, D. The absorption of inorganic phosphate from the small intestine of the rat. Exp. Physiol. 1956, 41, 398-340, doi:10.1113/expphysiol.1956.sp001211. [CrossRef]

43. Blaabjerg, K.; Jørgensen, H.; Tauson, A.; Poulsen, H. Heat-treatment, phytase and fermented liquid feeding affect the presence of inositol phosphates in ileal digesta and phosphorus digestibility in pigs fed a wheat and barley diet. Animal 2010, 4, 876-885, doi:10.1017/S1751731110000054. [CrossRef] [PubMed]

44. Metzler-Zebeli, B.; Molnár, A.; Hollmann, M.; Magowan, E.; Hawken, R.; Lawlor, P.; Zebeli, Q. Comparison of growth performance and excreta composition in broiler chickens when ranked according to various feed efficiency metrics. J. Anim. Sci. 2016, 94, 2890-2899. [CrossRef] [PubMed]

45. McCormack, U.; Curião, T.; Buzoianu, S.; Prieto, M.; Ryan, T.; Varley, P.; Crispie, F.; Magowan, E.; Metzler-Zebeli, B.; Berry, D. Exploring a possible link between the intestinal microbiota and feed efficiency in pigs. Appl. Environ. Microbiol. 2017, 83, e00380-17, doi:10.1128/AEM.00380-17. [CrossRef] [PubMed]

46. Sjöberg, P.; Thelin, P.; Rydin, E. Separation of inositol phosphate isomers in environmental samples by ion-exchange chromatography coupled with electrospray ionization tandem mass spectrometry. Talanta 2016, 161, 392-397, doi:10.1016/j.talanta.2016.08.076. [CrossRef] [PubMed]

47. Brady, S.; Callan, J.; Cowan, D.; McGrane, M.; O'Doherty, J. Effect of phytase inclusion and calcium/phosphorus ratio on the performance and nutrient retention of grower-finisher pigs fed barley/wheat/soya bean meal-based diets. J. Sci. Food Agric. 2002, 82, 1780-1790, doi:10.1002/jsfa.1262. [CrossRef]

48. Huber, K.; Zeller, E.; Rodehutscord, M. Modulation of small intestinal phosphate transporter by dietary supplements of mineral phosphorus and phytase in broilers. Poult. Sci. 2015, 94, 1009-1017, [CrossRef] [PubMed]

49. Dersjant-Li, Y.; Awati, A.; Schulze, H.; Partridge, G. Phytase in non-ruminant animal nutrition: A critical review on phytase activities in the gastrointestinal tract and influencing factors. J. Sci. Food Agric. 2015, 95, 878-896, doi:10.1002/jsfa.6998. [CrossRef] [PubMed]

50. Golovan, S.; Meidinger, R.; Ajakaiye, A.; Cottrill, M.; Wiederkehr, M.; Barney, D.; Plante, C.; Pollard, J.; Fan, M.; Hayes, M.; et al. Pigs expressing salivary phytase produce low-phosphorus manure. Nat. Biotechnol. 2001, 19, 741-745, doi:10.1038/90788. [CrossRef] [PubMed]

51. Cramer, C. Aspects of intestinal absorption of Ca, P and Mg. Methods Achiev. Exp. Pathol. 1972, 6, $172-192$.

52. Oster, M.; Nuchchanart, W.; Trakooljul, N.; Murani, E.; Zeyner, A.; Wirthgen, E.; Hoeflich, A.; Ponsuksili, S.; Wimmers, K. Methylating micronutrient supplementation during pregnancy influences foetal hepatic gene expression and IGF signalling and increases foetal weight. Eur. J. Nutr. 2016, 55, 1717-1727, doi:10.1007/s00394-015-0990-2. [CrossRef] [PubMed]

53. Letourneau-Montminy, M.; Narcy, A.; Dourmad, J.; Crenshaw, T.; Pomar, C. Modeling the metabolic fate of dietary phosphorus and calcium and the dynamics of body ash content in growing pigs. J. Anim. Sci. 2015, 93, 1200-1217. doi:10.2527/jas.2014-8519. [CrossRef] [PubMed]

54. Nicodemo, M.; Scott, D.; Buchan, W.; Duncan, A.; Robins, S. Effects of variations in dietary calcium and phosphorus supply on plasma and bone osteocalcin concentrations and bone mineralization in growing pigs. Exp. Physiol. 1998, 83, 659-665. [CrossRef] [PubMed]

55. Liesegang, A.; Ursprung, R.; Gasser, J.; Sassi, M.; Risteli, J.; Riond, J.; Wanner, M. Influence of dietary phosphorus deficiency with or without addition of fumaric acid to a diet in pigs on bone parameters. J. Anim. Physiol. Anim. Nutr. 2002, 86, 1-16, doi:10.1046/j.1439-0396.2002.00355.x. [CrossRef]

56. Sørensen, K.; Tauson, A.; Poulsen, H. Long term differentiated phosphorus supply from below to above requirement affects nutrient balance and retention, body weight gain and bone growth in growing-finishing pigs. Livest. Sci. 2018, 211, 14-20. [CrossRef] 
57. Heyer, C.; Weiss, E.; Schmucker, S.; Rodehutscord, M.; Hoelzle, L.; Mosenthin, R.; Stefanski, V. The impact of phosphorus on the immune system and the intestinal microbiota with special focus on the pig. Nutr. Res. Rev. 2015, 28, 67-82, doi:10.1017/S0954422415000049. [CrossRef] [PubMed]

58. Kegley, E.; Spears, J.; Auman, S. Dietary phosphorus and an inflammatory challenge affect performance and immune function of weanling pigs. J. Anim. Sci. 2001, 79, 413-419. [CrossRef] [PubMed]

59. Takayanagi, H. Osteoimmunology: Shared mechanisms and crosstalk between the immune and bone systems. Nat. Rev. Immunol. 2007, 7, 292-304. [CrossRef] [PubMed]

60. Okamoto, K.; Nakashima, T.; Shinohara, M.; Negishi-Koga, T.; Komatsu, N.; Terashima, A.; Sawa, S.; Nitta, T.; Takayanagi, H. Osteoimmunology: The conceptual framework unifying the immune and skeletal systems. Physiol. Rev. 2017, 97, 1295-1349, doi:10.1152/physrev.00036.2016. [CrossRef] [PubMed]

61. Ankra-Badu, G.; Pesti, G.; Aggrey, S. Genetic interrelationships among phosphorus, nitrogen, calcium, and energy bioavailability in a growing chicken population. Poult. Sci. 2010, 89, 2351-2355, doi:10.3382/ps.2010-00870. [CrossRef] [PubMed]

62. Beck, P.; Piepho, H.; Rodehutscord, M.; Bennewitz, J. Inferring relationships between Phosphorus utilization, feed per gain, and bodyweight gain in an F2 cross of Japanese quail using recursive models. Poult. Sci. 2016, 95, 764-773, doi:10.3382/ps/pev376. [CrossRef] [PubMed]

63. Beck, P.; Stratz, P.; Preuß, S.; Pitel, F.; Recoquillay, J.; Duval, E.; Rodehutscord, M.; Bennewitz, J. Linkage mapping of quantitative trait loci for phosphorus utilization and growth related traits in an F2-cross of Japanese quail (Coturnix japonica). Eur. Poult. Sci. 2016, 80, doi:10.1399/eps.2016.133. [CrossRef]

64. Alexander, L.; Qu, A.; Cutler, S.; Mahajan, A.; Lonergan, S.; Rothschild, M.; Weber, T.; Kerr, B.; Stahl, C. Response to dietary phosphorus deficiency is affected by genetic background in growing pigs. J. Anim. Sci. 2008, 86, 2585-2595, doi:10.2527/jas.2007-0692. [CrossRef] [PubMed]

65. Rothammer, S.; Bernau, M.; Kremer-Rücker, P.V.; Medugorac, I.; Scholz, A.M. Genome-wide QTL mapping results for regional DXA body composition and bone mineral density traits in pigs. Arch. Anim. Breed. 2017, 60, 51-59, doi:10.5194/aab-60-51-2017. [CrossRef]

66. Zhang, W.; Aggrey, S.; Pesti, G.; Edwards, H., Jr.; Bakalli, R. Genetics of phytate phosphorus bioavailability: Heritability and genetic correlations with growth and feed utilization traits in a randombred chicken population. Poult. Sci. 2003, 82, 1075-1079, doi:10.1093/ps/82.7.1075. [CrossRef] [PubMed]

67. Ponsuksili, S.; Trakooljul, N.; Hadlich, F.; Haack, F.; Murani, E.; Wimmers, K. Genetically regulated hepatic transcripts and pathways orchestrate haematological, biochemical and body composition traits. Sci. Rep. 2016, 6, 39614, doi:10.1038/srep39614. [CrossRef] [PubMed]

68. Ponsuksili, S.; Trakooljul, N.; Hadlich, F.; Haack, F.; Murani, E.; Wimmers, K. Genetic architecture and regulatory impact on hepatic microRNA expression linked to immune and metabolic traits. Open Biol. 2017, 7, 170101, doi:10.1098/rsob.170101. [CrossRef] [PubMed]

69. Meat Production Statistics—Statistics Explained. Available online: http://ec.europa.eu/eurostat/statisticsexplained/index.php/Meat_production_statistics\#Poultry_meat (accessed on 10 April 2018).

70. Pork Production up in the EU_Product_Eurostat. Available online: http:/ / ec.europa.eu/eurostat/en/ web/products-eurostat-news/- /DDN-20170919-1 (accessed on 10 April 2018).

71. Foged, H.; Flotats, X.; Blasi, A.; Palatsi, J.; Magri, A.; Schelde, K. Inventory of Manure Processing Activities in Europe. Available online: https://upcommons.upc.edu/bitstream/handle/2117/18943/21010_technical_ report_I_inventory.pdf?sequence=1\&isAllowed=y (accessed on 10 April 2018).

72. Helsinki-Commission. HELCOM Baltic Sea Action Plan; HELCOM Ministerial Meeting: Krakow, Poland, 2007.

73. Aloe, A.; Bouraoui, F.; Grizzetti, B.; Bidoglio, G.; Pistocchi, A. Managing Nitrogen and Phosphorous Loads to Water Bodies: Characterizations and Solutions; European Commission, Joint Research Centre, Institute for Environment and Sustainability: Ispra, Italy, 2014.

74. Połtowicz, K.; Doktor, J. Effect of free-range raising on performance, carcass attributes and meat quality of broiler chickens. Anim. Sci. Pap. Rep. 2011, 29, 139-149.

75. Verheijen, L.; Wiersema, D.; Hulshoff Pol, L.; De Wit, L. Livestock and the Environment: Finding a Balance: Management of Waste from Animal Product Processing; International Agricultural Centre (IAC): Wageningen, The Netherlands, 1996.

76. Lessler, J.; Ranells, N. Grower Guidelines for Poultry and Fowl Processing; North Carolina State University Cooperative Extension: Raleigh, NC, USA, 2007. 
77. McCrackin, M.L.; Gustafsson, B.; Hong, B.; Howarth, R.; Humborg, C.; Savchuk, O.; Svanbäck, A.; Swaney, D. Opportunities to reduce nutrient inputs to the Baltic Sea by improving manure use efficiency in agriculture. Reg. Environ. Chang. 2018, 1-12, doi:10.1007/s10113-018-1308-8. [CrossRef]

78. Lebuf, V.; Accoe, F.; Van Elsacker, S.; Vaneeckhaute, C.; Michels, E.; Meers, E.; Ghekiere, G.; Ryckaert, B. Techniques for Nutrient Recovery From Digestate: Inventory. Available online: https:/ /biblio.ugent.be/ publication/7010573 (accessed on 10 April 2018).

79. Vaneeckhaute, C.; Lebuf, V.; Michels, E.; Belia, E.; Vanrolleghem, P.; Tack, F.; Meers, E. Nutrient recovery from digestate: Systematic technology review and product classification. Waste Biomass Valorization 2017, 8, 21-40, doi:10.1007/s12649-016-9642-x. [CrossRef]

80. Yue, K.; Yang, W.; Peng, Y.; Peng, C.; Tan, B.; Xu, Z.; Zhang, L.; Ni, X.; Zhou, W.; Wu, F. Individual and combined effects of multiple global change drivers on terrestrial phosphorus pools: A meta-analysis. Sci. Total Environ. 2018, 630, 181-188, doi:10.1016/j.scitotenv.2018.02.213. [CrossRef] [PubMed]

81. Turner, B.; Frossard, E.; Baldwin, D. (Eds.) Organic Phosphorus in the Environment; CABI International: Wallingford, UK, 2005.

82. Ackerly, D.; Stuart, S. Physiological Ecology: Plants. In The Princeton Guide to Ecology; Princeton University Press: Woodstock, UK, 2009.

83. Schindler, D.; Vallentyne, J. The Algal Bowl: Over Fertilization of the World's Freshwaters and Estuaries; University of Alberta Press: Edmonton, AB, Canada, 2008.

84. Ceulemans, T.; Stevens, C.; Duchateau, L.; Jacquemyn, H.; Gowing, D.; Merckx, R.; Wallace, H.; van Rooijen, N.; Goethem, T.; Bobbink, R.; et al. Soil phosphorus constrains biodiversity across European grasslands. Glob. Chang. Biol. 2014, 20, 3814-3822. [CrossRef] [PubMed]

85. Rillig, M. Arbuscular mycorrhizae and terrestrial ecosystem processes. Ecol. Lett. 2004, 7, 740-754, doi:10.1111/j.1461-0248.2004.00620.x. [CrossRef]

86. Isbell, F.; Adler, P.; Eisenhauer, N.; Fornara, D.; Kimmel, K.; Kremen, C.; Letourneau, D.; Liebman, M.; Polley, H.; Quijas, S.; et al. Benefits of increasing plant diversity in sustainable agroecosystems. J. Ecol. 2017, 105, 871-879. [CrossRef]

87. Garnache, C.; Swinton, S.; Herriges, J.; Lupi, F.; Stevenson, R. Solving the phosphorus pollution puzzle: Synthesis and directions for future research. Am. J. Agric. Econ. 2016, 98, 1334-1359, doi:10.1093/ajae/aaw027. [CrossRef]

88. Goff, J. Invited review: Mineral absorption mechanisms, mineral interactions that affect acid-base and antioxidant status, and diet considerations to improve mineral status. J. Dairy Sci. 2018, 101, 2763-2813, doi:10.3168/jds.2017-13112. [CrossRef] [PubMed]

89. Janssen, S.; Van Ittersum, M.K. Assessing farm innovations and responses to policies: A review of bio-economic farm models. Agric. Syst. 2007, 94, 622-636, doi:10.1016/j.agsy.2007.03.001. [CrossRef]

90. Louhichi, K.; Kanellopoulos, A.; Janssen, S.; Flichman, G.; Blanco, M.; Hengsdijk, H.; Heckelei, T.; Berentsen, P.; Lansink, A.; Van Ittersum, M. FSSIM, a bio-economic farm model for simulating the response of EU farming systems to agricultural and environmental policies. Agric. Syst. 2010, 103, 585-597, doi:10.1016/j.agsy.2010.06.006. [CrossRef]

91. Belhouchette, H.; Louhichi, K.; Therond, O.; Mouratiadou, I.; Wery, J.; Van Ittersum, M.; Flichman, G. Assessing the impact of the Nitrate Directive on farming systems using a bio-economic modelling chain. Agric. Syst. 2011, 104, 135-145, doi:10.1016/j.agsy.2010.09.003. [CrossRef]

(C) 2018 by the authors. Licensee MDPI, Basel, Switzerland. This article is an open access article distributed under the terms and conditions of the Creative Commons Attribution (CC BY) license (http://creativecommons.org/licenses/by/4.0/). 